Agriculture, Agribusiness and Biotechnology

Vol.59: e16160280, January-December 2016 http://dx.doi.org/10.1590/1678-4324-2016160280 ISSN 1678-4324 Online Edition

BRAZILIAN ARCHIVES OF BIOLOGY AND TECHNOLOGY

AN INTERNATIONAL JOURNAL

\title{
Identification and characterization of Fusarium mangiferae as pathogen of mango malformation in India
}

\author{
Pradeep Kumar $^{1 *}$; Madhu Kamle²; Asok Kumar Misra ${ }^{3}$; Anthonia O'Donovan ${ }^{4}$; Marcela \\ Pagano5; Dinesh Raj Modi ${ }^{6}$. \\ ${ }^{1}$ Yeungnam University, School of Biotechnology, Gyeongsan, Korea; ${ }^{2}$ Ben-Gurion University of the Negev, Dryland \\ Agriculture and Biotechnology, Beer-Sheva, Israel; ${ }^{3}$ Central Institute for Subtropical Horticulture Lucknow, Uttar \\ Pradesh, India; ${ }^{4}$ National University of Ireland, Discipline of Biochemistry, Galway, Ireland; ${ }^{5}$ Lunds Universitet, \\ Department of Biology, Lund, Sweden; ${ }^{6}$ Babasaheb Bhimrao Ambedkar University, Department of Biotechnology, \\ Lucknow, Uttar Pradesh, India;
}

\begin{abstract}
Fusarium mangiferae ( $=F$. subglutinans) isolates collect from malformed samples from major mango-growing area of North India. Molecular identification and characterization of eleven most virulent isolates of $F$. mangiferae, based on pathogenicity tests used for the present study. Species-specific, genus specific ITS-PCR and PCR-RFLP performed for the accurate and easy detection of $F$. mangiferae. The rDNA-ITS $28 S$ region sequences used for phylogenetic analysis of Fusarium isolates from India and other countries for homology search between them. The phylogenetic tree divided the isolates into three clades (i.e., American, Asian and African) and showed the high level of sequence based similarity (69-99\%) among all Fusarium sequences from Asia. Thus, claimed Fusarium mangiferae as dominant pathogen of mango malformation. Furthermore, we conclude that exploiting the nested PCR coupled with PCR-RFLP will help in rapid and accurate detection of $F$. mangiferae pathogen of mango malformation.
\end{abstract}

Key words: Fusarium mangiferae, detection, phylogenetic analysis, vegetative malformation, floral malformation.

\footnotetext{
${ }^{1}$ Authors for correspondence: pkbiotech@gmail.com
} 


\section{INTRODUCTION}

The Mango 'King of Fruits' is the most delicious fruit commonly grown in Southern Asia. Mango malformation emerge as most threatening constraint that limits Mango production and cause severe economic losses (10-90\%) to stakeholders of tropical and subtropical countries ${ }^{[1-2]}$. The most visible symptoms of mango malformation were malformed flower and bunchy appearance of vegetative tissues. Panicles affected become small, do not bear fruits and aborted prematurely. The variability of malformation pathogen influenced by environmental conditions and agro-climatic regions. Disease spread severely in new areas by malformation of mature trees and infected seedlings [3]. In spite of several decades of never-ending research, the etiology of the disease becomes a contentious issue and no effective control measure yet known ${ }^{[4]}$. However, various fungicides assessed for their ability to control the pathogen under laboratory, greenhouse and field conditions ${ }^{[5]}$, but still unable to cure completely in the field conditions. Several biotic and abiotic factors reported to affect mango malformation disease. Fungi is the most counted factor reported ${ }^{[6]}$. Summanwar ${ }^{[7]}$ first reported the malformation caused by $F$. moniliforme Shield and proved its pathogenicity in India. F. mangiferae Britz, Wingfield \& Marasas is universal spread pathogen of mango and isolated from Egypt, Florida (USA) and Israel. $F$. mangiferae (earlier reported $=F$. subglutinans) isolated from floral and vegetative malformed tissues ${ }^{[8]}$ as evidenced by cultural and morphological data. Histopathological studies of floral and vegetative tissues confirmed the association of $F$. mangiferae ${ }^{[9]}$. According to recent classification, $F$. subglutinans now registered as $F$. mangiferae causing mango malformation disease ${ }^{[6,}$ 10-13].

Disease management strategies required for detection and identification of damaging pathogens but also understand the pathogen threshold density, interaction between the pathogens and environments ${ }^{[14]}$. In associate with continuous monitoring and basic pathological techniques that are tedious, it is complementary to perform molecular characterization at genus and species level for significant management of disease incidence. Internal transcribed spacer (ITS) regions are highly conserved within fungal species (with intra-specific similarities $>99 \%$ ) but are variable between species and accepted by fungal taxonomists ${ }^{[15-16]}$. The rDNA ITS sequences have been successfully used in resolving species-level and phylogenetic relationships in Fusarium ${ }^{[17-18]}$. The ITS along with 5.8S rDNA region amplified using ITS primer-pairs ${ }^{[19]}$ which discern genetic variation in the population studied. Earlier, molecular characterization confirmed the association of $F$. mangiferae with mango malformation ${ }^{[20-21]}$. In this study, we developed species-specific and $\beta$-tubulin gene specific markers for identification of $F$. mangiferae isolates from mango malformed samples and their sequence based phylogenetic analysis to understand the diversity relationship among the Indian isolates compared with other countries geographical location.

\section{MATERIAL AND METHODS}

\section{Isolation of Pathogen and Pathogenicity Test}

The vegetative and floral malformed samples collected from different orchards of mango (Table 1), cultured on Potato Dextrose Agar (PDA, HiMedia)and incubate at $28 \pm 2^{\circ} \mathrm{C}$ for 6 days. Cultural and microscopic studies confirmed pathogens as F. mangiferae ${ }^{[22]}$. Pure culture using single spore and hyphal tip isolation techniques by following Koch's postulates ${ }^{[23]}$. Pathogenicity tests for all isolates performed on the mango seedlings of Dashehari cultivar (sensitive to disease) under field conditions as well as in greenhouse conditions with controlled humidity at $85 \%$ and temperature $10-25$ ${ }^{\circ} \mathrm{C}$. Pure cultures from each representative isolate used for inoculation in November to the host tissue covered with sterile moist cotton. Prior to inoculation, buds treated with $20 \%$ hydrogen peroxide $\left(\mathrm{H}_{2} \mathrm{O}_{2}\right)$ which detoxified mangiferin (the host defense anti Fusarium compound) as described by Chand and Chakrabarti ${ }^{[24]}$.

\section{DNA Isolation}

Fresh mycelium from all 11 representative isolates collected for genomic DNA extraction according to the protocol of Abd-Elsalam et al ${ }^{[25]} .100 \mathrm{mg}$ mycelium homogenized using $300 \mu \mathrm{l}$ of extraction buffer containing $200 \mathrm{mM}$ Tris- $\mathrm{HCl}$ (pH 8.5), 250 $\mathrm{mM} \mathrm{NaCl}, 25 \mathrm{mM}$ EDTA and $0.5 \%$ of sodium dodecyl sulphate and centrifuged at maximum speed for $5 \mathrm{~min}$. Add $150 \mu \mathrm{l}$ sodium acetate $(\mathrm{pH}$ 5.2) to the samples and chilled in ice for $10 \mathrm{~min}$. Centrifuged at 13,000 rpm for $5 \mathrm{~min}$ and collect supernatant in new tube. Add equal volume of isopropanol and mix by inverting the tubes gently. 
Centrifuge samples at $14,000 \mathrm{rpm}$ for $20 \mathrm{~min}$ at $4^{\circ} \mathrm{C}$ and collect DNA pellet, washed pellet twice with $70 \%$ ethanol to remove excess salt. Finally, the isolated DNA dissolved in a minimum quantity of Tris-EDTA $(10 \mathrm{mM})$ buffer and stored at $-20^{\circ} \mathrm{C}$ until use. Quantification and purity of DNA recorded using standard spectroscopic methods at an absorbance wavelength of $260 \mathrm{~nm}^{\text {[26] }}$.

\section{ITS-PCR}

ITS-PCR for isolates performed by adopting the protocol described by Abd- Elsalam et al. ${ }^{[25]}$. PCR reactions for amplification of ITS regions were performed using the ITS1 5'TCCGTAGGTGAACCTGCGG 3' and ITS4 3' TCCTCCGCTTATTGATATGC 5' primer pair ${ }^{[19]}$ in reaction volumes of $50 \mu \mathrm{l}$ containing $25 \mathrm{ng}$ of genomic DNA, 1X PCR buffer (Invitrogen), 0.20 $\mathrm{mM}$ of each dNTP (Invitrogen), $1.5 \mathrm{mM} \mathrm{MgCl} 2,1$ $\mu \mathrm{M}$ primers and $1 \mathrm{U}$ Taq polymerase (Invitrogen). DNA amplification was performed in a Thermal Cycler (Eppendorf) and the program consisted of an initial denaturing step at $94^{\circ} \mathrm{C}$ for $1 \mathrm{~min}$, followed by 30 cycles of $60 \mathrm{~s}$ at $94^{\circ} \mathrm{C}, 2 \mathrm{~min}$ at $58^{\circ} \mathrm{C}$ and 60 $\mathrm{s}$ at $72^{\circ} \mathrm{C}$ and a final extension step of $5 \mathrm{~min}$ at $72^{\circ} \mathrm{C}$.

\section{Genus and $\beta$-Tubulin Gene-Specific PCR}

PCR for Fusarium isolates using primers ITS-Fu-F and ITS-Fu-R for genus-specific PCR performed as given description by Kamel et al ${ }^{[27]}$. The primer pair specific to Fusarium spp. ITS-Fu-F 5' CAACTCCCAAACCCCTGTGA 3' and ITS-Fu-R 5' GCGACGATTACCAGTAACGA 3'. PCR reaction conditions described using ITS1 and ITS4 followed. Fusarium species reported to characterize at the molecular level using $\beta$-tubulin gene specific primers. Highly specific $\beta$-tub $F$ 5'TGCTTCGGCGGGTAGGGTC 3 ' and $\beta$-tub R 5' ACGCAAAGGAGGCTCCGGGA 3' primers used. PCR reactions for gene specific amplification were performed in reaction volumes of $50 \mu \mathrm{l}$ containing $25 \mathrm{ng}$ of genomic DNA, 1X PCR buffer (Invitrogen), $0.20 \mathrm{mM}$ of each dNTP (Invitrogen), $1.5 \mathrm{mM} \mathrm{MgCl}_{2}, 1 \mu \mathrm{M}$ primers, and $1 \mathrm{U} \mathrm{Taq}$ polymerase (Invitrogen). PCR amplification was performed in a Thermal Cycler (Eppendorf) and the program consisted of an initial denaturing step at $94^{\circ} \mathrm{C}$ for $1 \mathrm{~min}$, followed by 30 cycles of $60 \mathrm{~s}$ at $94^{\circ} \mathrm{C}, 2$ min at $58^{\circ} \mathrm{C}$ and $60 \mathrm{~s}$ at $72^{\circ} \mathrm{C}$; and a final extension step of $5 \mathrm{~min}$ at $72^{\circ} \mathrm{C}$. PCR products were analyzed using $2.0 \%$ Agarose gel electrophoresis.

\section{PCR-RFLP}

PCR-RFLP performed as per the protocol described by Bogale et al. ${ }^{[28]}$ with minor modifications and the reaction conditions were standardized. For ITSRFLP, restriction digestion of PCR products of all isolates carried out by a single digestion using restriction enzymes, viz., Alu I, Msp I, Rsa I and Taq I (Fermantas). The digestion reaction conditions include $1 \mathrm{X}$ buffer, $10 \mathrm{U} / \mu \mathrm{l}$ of enzyme and $100 \mu \mathrm{g}$ of PCR product for a total reaction volume of $25 \mu$. The restriction digestion reactions carried out by incubation at $37^{\circ} \mathrm{C}$ for $2-3 \mathrm{hrs}$. The digested samples analyzed on $2.5 \%$ Agarose gel electrophoresis with control (undigested PCR product) and molecular size standard markers (100 bp DNA ladder).

\section{Sequencing and Phylogenetic Analyses}

The PCR products of 11 isolates purified using a QIA quick PCR purification Kit (Qiagen $\mathrm{GmbH}$, Germany). Representative Fusarium isolates sequenced in both directions with primers ITS1 and ITS4. Reactions were performed on an ABI PRISM 377 automated DNA sequencer with an ABI PRISM Dye Terminator Cycle ready reaction Kit (Perkin-Elmer, Warrington, UK). Sequence-based comparative analyses of Fusarium performed using reference sequences retrieved from NCBI-Genbank and search algorithm BLAST ${ }^{[29]}$. Multiple sequence alignments performed using ClustalW algorithm ${ }^{[30]}$. For phylogenetic analyses, ITSrDNA sequences aligned manually by inserting gaps and checked for accuracy. Fusarium and Giberrella isolates selected from GenBank were at least $90 \%$ identical, determined using the molecular evolutionary genetics analysis (MEGA) version 5.05 software [31]. One thousand Bootstrap replicates employed to determine confidence in the branches order.

\section{RESULTS}

\section{Cultural and Pathogenicity Bioassays}

The morphological and cultural characterization of the 11 isolates grow on PDA medium studied and compared with those mentioned by Booth ${ }^{[22]}$. The mycelium show high-level variability in character with colony and metabolite color as described (Table 1). The size and shape of the different types of micro and macro conidia produced by the isolates draw and measured by Leica LEITZ DMRBE Microscope (Germany). Micro-conidia 
had aseptate hyaline, mostly oval and typically borne on polyphialides and the size range of $7.8 \mathrm{X}$ $2.8 \mu \mathrm{m}$. Macroconidia thin walled, falcate with mostly 2-3 septate and the size range of $25 \times 42$ $\mu \mathrm{m}$. All isolates showed positive pathogenicity test in three replicates performed on seedlings of Dashehari in controlled greenhouse conditions and in field. Bud swelling and scale like leaf disease symptoms appeared approximately 2-3 months after the inoculation. Complete symptom appearance was achieved after 6-7 months and recovery of the pathogen performed to prove the 'Koch's Postulates'. However, no malformation symptoms noticed in the control sets.

Table 1. Cultural and morphological characters of $11 \mathrm{~F}$. mangiferae isolates collected from different agro-ecological regions of India.

\begin{tabular}{ccccccc}
\hline $\begin{array}{c}\text { Sample } \\
\text { No. }\end{array}$ & $\begin{array}{c}\text { Place of } \\
\text { sample } \\
\text { collection }\end{array}$ & $\begin{array}{c}\text { Isolates } \\
\text { name }\end{array}$ & Symptom & $\begin{array}{c}\text { Culture } \\
\text { colour }\end{array}$ & $\begin{array}{c}\text { Metabolite } \\
\text { colour }\end{array}$ & Spore \\
\hline 1 & Sabour & F1 & FM & Light pink & Pink & +++ \\
2 & Sabour & F2 & FM & Cream & pink & ++ \\
3 & Dholi & F3 & VM & Light Pink & Light brown & +++ \\
4 & Ranchi & F4 & FM & Light Pink & Dark red & ++ \\
5 & Lucknow & F5 & VM & Yellow & Pink & ++ \\
6 & Lucknow & F6 & VM & Pink & Purple & +++ \\
7 & Lucknow & F7 & VM & Pink & Light pink & ++ \\
8 & Chittour & F8 & VM & purple & Violet & ++ \\
9 & Bangalore & F9 & FM & Red & Light brown & +++ \\
10 & Shaharanpur & F10 & FM & Light pink & Purple & +++ \\
11 & Shaharanpur & F11 & FM & Purple pink & Purple & +++ \\
& & & & & & \\
\hline
\end{tabular}

VM: Vegetative malformation; FM: Floral malformation; ++ Moderate spore; +++ High Spores

\section{Molecular Characterization}

Genomic DNA of all 11 isolates of $F$. mangiferae and control sample successfully amplified using ITS1 (5'TCCGTAGGTGAACCTGCGG3') and ITS4 (5, TCCTCCGCTTATTGATATGC 3') primers ${ }^{[19]}$ obtained 570 bp band (Fig. 1a). Fusarium genus-specific primer ITS-Fu-f and ITSFu-r ${ }^{[27]}$ specifically amplified a 398 bp band among all the isolates (Fig. 1b). No cross-reaction amplification detected in negative control Colletotrichum gloeosporioides tested for nonspecific amplification. The PCR-RFLP restriction digestions of Fusarium isolates performed using AluI, HindIII and RsaI restriction enzymes. Hind III and $R s a$ I show no restriction sites. However, AluI restriction gives two clear restriction bands of 410 bp and $120 \mathrm{bp}$. The gene specific PCR using $\beta$ tubulin primers resulted in a single band of $235 \mathrm{bp}$ and no amplification in negative control. Hence, $\beta$ tubulin primer-pair can potentially employed as marker to discriminate $F$. mangiferae (Fig. $1 \mathrm{c} \& \mathrm{~d}$ ).

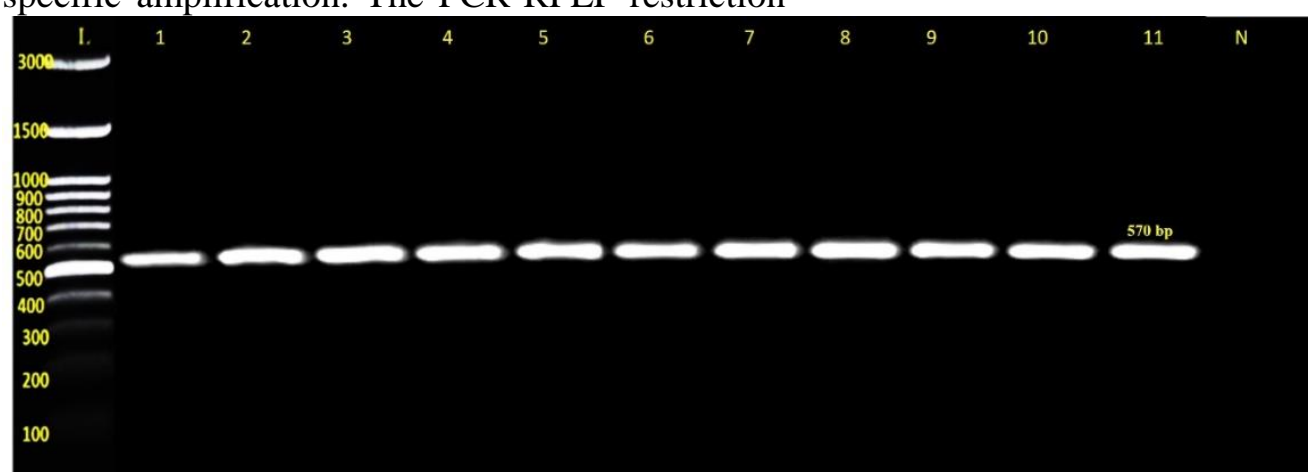

Fig 1 (a) ITS-PCR of 11 representative isolates of F.mangiferae using ITS1-4 primer (White et al.1990) amplify a common 570 bp band among all isolates. 


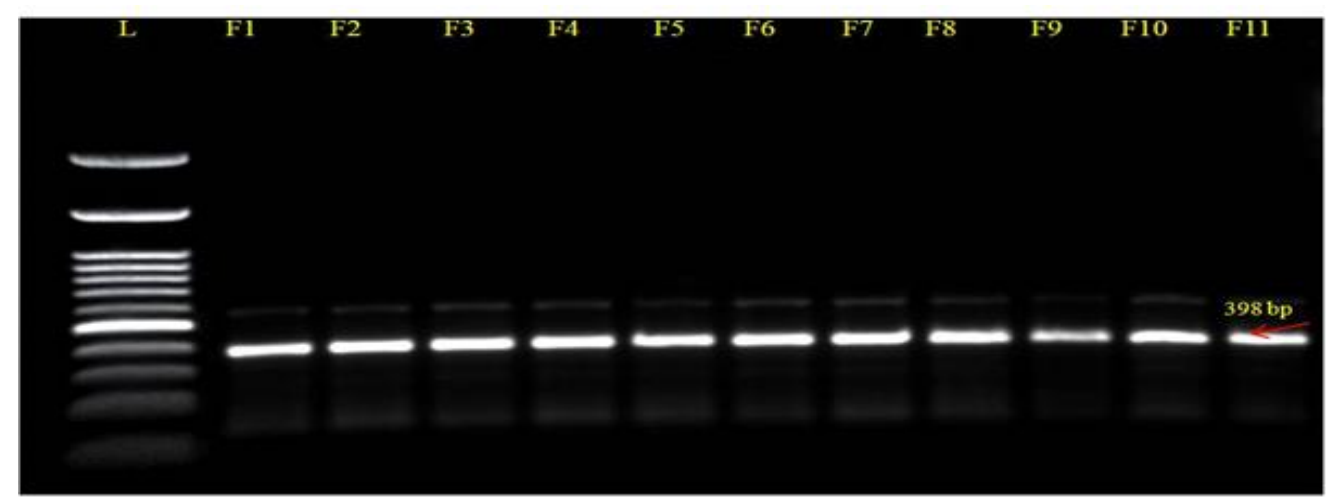

Fig1 (b): PCR amplification using Genus-specific primer of $F$. mangiferae isolates using ITS-Fu F\&R primers (Abd-Elsalam, 2003).

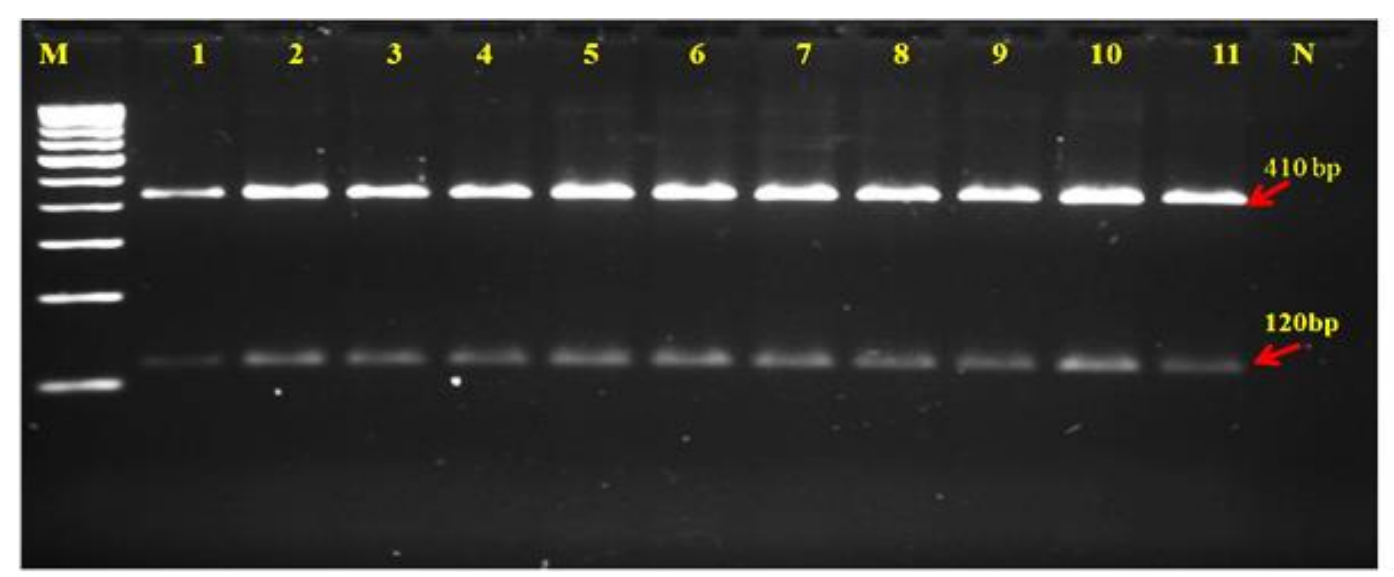

Fig1(c): PCR-Restriction digestion with AluI. (Lane 1-11 F. mangiferae; N- F. oxysporum (Negative control).

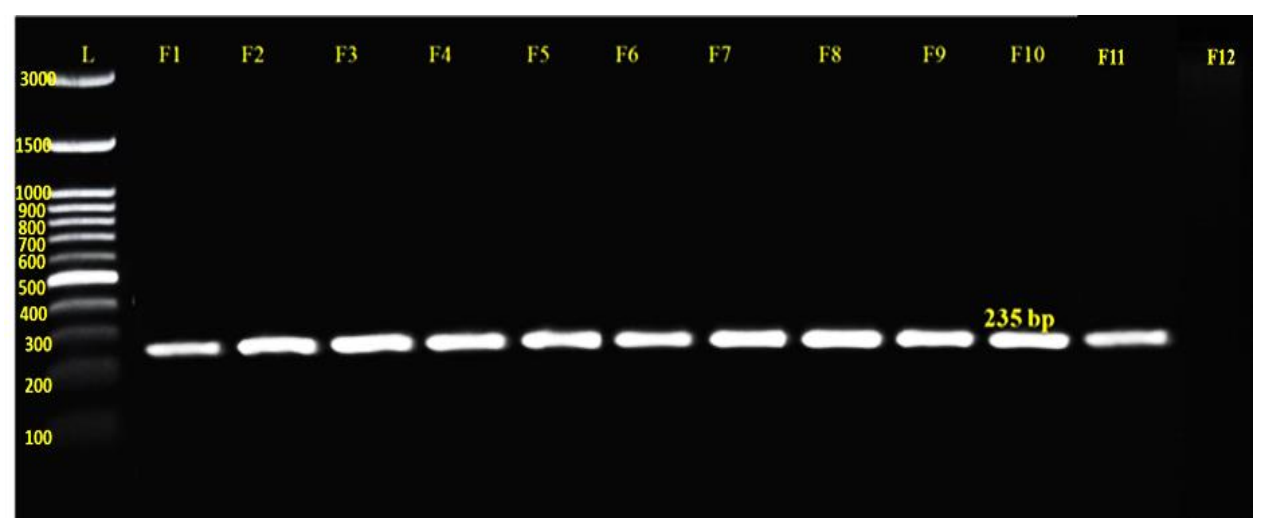

Fig 1(d). Nested-PCR using beta-tubulin $(\beta$-tub) gene-specific primer (Lane 1-11) F. mangiferae and lane 12- Negative control (C. gloeosporioides).

\section{Phylogenetic Analysis}

Twenty-two sequences of Fusarium spp. reported to cause mango malformation from different countries (China, Italy, Brazil, Korea, South Africa and USA) selected and retrieved from NCBI. Three Fusarium isolates from present study submitted to NCBI (Accession id: JN646038, JN646039,
JN646040) with less than 90\% sequence homology with the available Fusarium spp. reference sequences for phylogenetic analysis. All the sequences nBLAST-NCBI for sequence homology and multiple sequence alignment performed using ClustalW algorithm and phylogenetic tree constructed using MEGA 5.05 ${ }^{[31]}$. The comparative 
phylogenetic tree constructed using 22 Fusarium spp. isolates from other countries along with the three representative isolates from the present study showed more than $90 \%$ nucleotide sequence similarity and grouped the isolates into two major clusters I and II. Cluster I further divided into two major subgroups covering the present study
Fusarium isolates (India) and isolates from Brazil, USA, Italy, China and Korea. However, cluster II divided into two sub clades covering the two Fusarium spp. of South Africa and depicts genetic variability at the species level (Fig. 2).

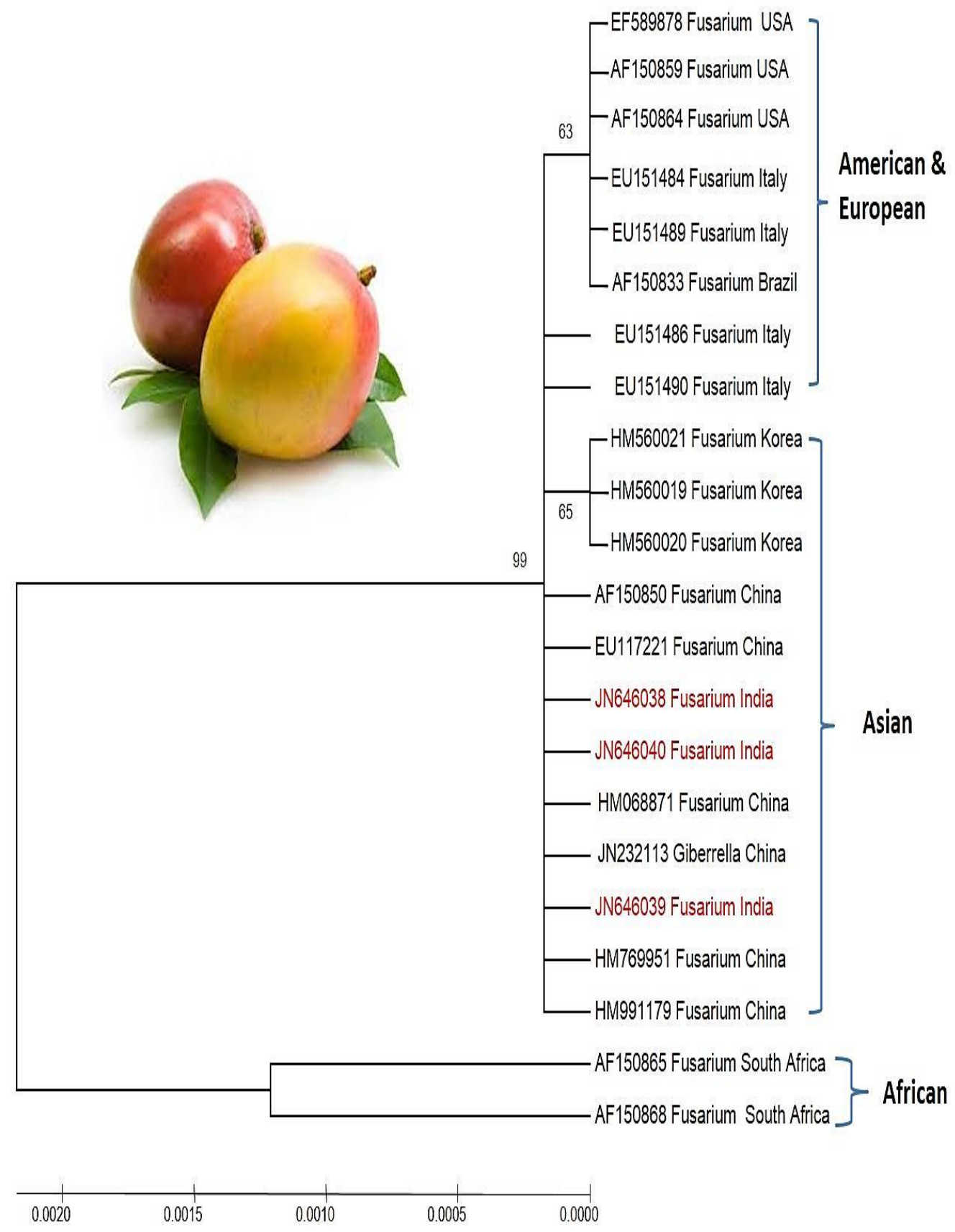

Fig 2. Phylogenetic tree constructed using MEGA 5.05 version with ITS region sequences retrieved randomly from the GenBank along with the present study isolates (in red). 


\section{DISCUSSION}

Normal apical growth observed on the apex of healthy seedlings while seedlings inoculated with $F$. mangiferae showed vegetative malformed growth followed by excessive proliferation of leaves. The gathering of stubby leaves into close folds similar to incipient bunchy top met under natural normal conditions, which is in accordance with previous workers ${ }^{[9,32]}$ on pathogenicity. Early and easy disease detection of $F$. mangiferae is necessary for effective and timely management of mango malformation. PCR based molecular disease diagnostic techniques provide a rapid, costeffective specific and sensitive detection system in comparison to conventional methods ${ }^{[33]}$. Globally, three Fusarium species under the Giberrella fuzikoroi species complex reported as the causal agents of mango malformation disease. The species are $F$. mangiferae from Egypt ${ }^{[3]}$, Israel ${ }^{[34]}$, South Africa ${ }^{[10]}$, Pakistan ${ }^{[35]}, F$. proliferatum from Malaysia [36], and F. subglutinans reported from South Africa, India and USA ${ }^{[37]}$. PCR products of $570 \mathrm{bp}, 398 \mathrm{bp}$ and $235 \mathrm{bp}$ amplified in $F$. mangiferae using Fusarium species-specific ${ }^{[25]}$ ITS primers and $\beta$-tubulin gene-specific primers, respectively. By contrast, the nested PCR approach presented here produced consistent and reproducible results using $\beta$-tubulin gene-specific designed primers. Nested PCR increased the sensitivity of $F$. mangiferae ( $=F$. subglutinans) $\beta$ tubulin gene-specific primers by 1000 fold ${ }^{[38]}$. The nested PCR assay potentially employed as a diagnostic tool for effective detection of $F$. mangiferae in mango malformation affected tissues. Moreover, nested PCR permits rapid identification of the fragmented samples and does not require sequencing. This technique is advantageous as it is rapid, reliable and robust. However ITS-PCR-RFLP using Alu I restriction enzyme proficiently identifies the pathogen by giving two clear bands of 410 and $120 \mathrm{bp}$ sizes and making it an effective marker for $F$. mangiferae.

The phylogenetic tree constructed using ITS-gene sequences comparing Fusarium spp. associated with mango malformation disease from different countries (Brazil, China, USA, Korea, Italy and South Africa) indicate a wide diversity among $F$. mangiferae isolates. This range is consistent with the previous description of isolates reported to cause malformation by $F$. subglutinans belongs to the same species within the G. fuzikoroi complex
[39]. Twenty-two Fusarium species associated with mango malformation in the G. fuzikoroi complex along with the present study isolates (JN646038, JN646039, and JN646040) divided into three distinct clades Asian clade, American clade and African clade. The phylogenetic tree showed 65$99 \%$ as overall genetic similarity between the isolates in two clusters. Cluster I is a major cluster and is further divided into group A comprising 8 Fusarium species (American and European clade) and group B comprising 12 Fusarium species (Asian clade). Cluster II is a minor cluster and is divide into two groups (South African clade). Based on sequence similarity of Fusarium spp. we concluded that the $F$. mangiferae is a dominant pathogen of mango malformation disease in India. Our findings are consistent and supports the findings of several research groups that identified and reported $F$. mangiferae as a pathogen causing mango malformation disease in Asia and America ${ }^{[37,40]}$. Similarly, American isolates sequences also supports that $F$. mangiferae is a mango malformation pathogen. However, the South African Fusarium species showed some level of distinctness as the clade represented by two Fusarium spp. viz. F. sterilihyphosum and $F$. subglutinans. Therefore, in the present study attempted, we develop a nested PCR based detection assay and sequence based phylogenetic analysis thus, claimed $F$. mangiferae as the dominant pathogen of mango malformation in India.

\section{CONCLUSION}

The ITS PCR based species-specific and genespecific detection and identification of Fusarium species isolates will be helpful in understanding the pathogenic relationship among the isolates from other geographical location. Identification and confirmation of $F$. mangiferae as the dominant pathogen of mango malformation disease in India. This PCR based technique would be a valuable component in large-scale pathogen diagnosis and confirmation. This study further explored beside effective crop management strategies.

\section{REFERENCES}

1. Crane JH, Campbell CW. The Mango. The Horticultural Science Department, Florida Cooperative Extension Service. Institute of Food and Agricultural Sciences, University of Florida. 1994. 
2. Kumar P, Misra AK, Modi DR. Current status of mango malformation in India. Asian JPlant Sci. 2011; 10: 1-23.

3. Ploetz R, Zheng QI, Vazquez A, Sattar A MA. Current status and impact of mango malformation in Egypt. Intern J Pest Manag. 2002; 48: 279-285.

4. Bains $G$ and Pant RC. Mango malformation: Etiology and preventive measures. Physiol Mol Biol Plant. 2003; 9: 41-61.

5. Freeman S, Maymon M, Biton A, Levin AG, Shtienberg D. Management of mango malformation disease based on a novel strategy of timing of fungicide applications combined with sanitation. Crop Protection. 2014; 61:84-91.

6. Steenkamp ET, Britz H, Coutinho TA, Wingfield BD, Marasas WFO, Wingfield MJ. Molecular characterization of Fusarium subglutinans associated with mango malformation. Mol Plant Pathol. 2000; 1: 187-193.

7. Summanwar AS, Raychaudhuri SP, Pathak SC. Association of fungus Fusarium moniliforme Sheld with the malformation in mango. Ind Phytopathol. 1966; 19: 227-228.

8. Kumar P, Misra AK, Srivastava AK, Modi DR. Mapping of Fusarium moniliforme var. subglutinans from normal and malformed panicles and seedlings of mango by recovery method. Plant Arch. 2011; 11: 567-569.

9. Kumar P, Kamle M, Gupta VK, Pandey BK, Misra AK, Modi DR. Host-pathogen interaction studies in malformed affected tissues of Mangifera indica L. Amer J Agri Biol Sci. 2013; 8 (3): 199-203.

10. Britz H, Steenkamp ET, Coutinho TA, Wingfield BD, Marasas WFO, Wingfield MJ. Two new species of Fusarium section Liseola associated with mango malformation. Mycologia. 2002; 94: 722730

11. Leslie JF, Summerell BA. The Fusarium Laboratory Manual. Ames, IO, USA: Blackwell Professional. 2006.

12. Chakrabarti DK. Mango Malformation. SpringerNetherlands. 2011; 148. ISBN-978-94-007-0362-9.

13. Newman Z, Freeman S, Biton I, Saada D, Paz T. Molecular diagnosis of mango malformation disease and phylogeny of Fusarium mangiferae. Phytoparasitica. 2012; 40: 287-297.

14. Li W, Li D, Twieg E, Hartung JS, Levy L. Optimized quantification of unculturable Candidatus Liberibacter spp. in host plants using real-time PCR. Plant Dis. 2008; 92: 854-861.

15. Gomes EA, Kasaya MC, de Barros EG, Borgs AC, Araujo EF. Polymorphism in the internal transcribed spacer (ITS) of the ribosomal DNA of 26 isolates of ectomycorrhizal fungi. Genet $\mathrm{Mol}$ Biol. 2002; 25(4): 477-483.

16. O'Brien HE, Parrent JL, Jackson JA, Moncalvo JM, Vilgalys R. Fungal communities' analysis by large-scale sequencing of environmental samples. Environ Microb. 2005; 71(1): 5544-5550.

17. O'Donnell K, Cigelnik E, Nirenberg HI. Molecular systematics and phylogeography of the Gibberella fujikuroi species complex. Mycologia. 1998; 90: 465-493.

18. Kvas M, Marasas WFO, Wingfield BD, Wingfield MJ, Steenkamp ET. Diversity and evolution of Fusarium species in the Gibberella fujikuroi complex. Fungal Diversity. 2009;1: 1-21.

19. White TJ, Bruns T, Lee S, Taylor J. Amplification and direct sequencing of fungal ribosomal RNA genes for phylogenetics. In: PCR Protocols: a guide to methods and applications. (Innis MA, Gelfand DH, Sninsky JJ, White TJ, eds). Academic Press, New York, USA. 1990; 315-322.

20. Arif M, Pani DR, Zaidi NW, Singh US. PCR-based identification and characterization of Fusarium sp. associated with mango malformation. Biotech Res Int. 2011, Article ID 141649, 6 pages.

21. Kumar P, Gupta VK, Misra AK, Modi DR. Molecular characterization of Fusarium moniliforme var. subglutinans isolates. J Environ Biol. 2014; 35(1): 211-216.

22. Booth C. The genus Fusarium. Commonwealth Mycological Institute, Kew, Surrey, UK. 1971; pp237.

23. Ali NA, Jackson RM. Stimulation of germination of spores of some ectomycorrhizal fungi by other microorganisms. Mycol Res. 1989; 93:182-186.

24. Chand D, Chakrabarti DK. Techniques to produce malformation in mango (Mangifera indica L.). Mycol Plant Pathol. 2003; 33: 431-438.

25. Abd-Elsalam KA, Schneider F, Guo JR. A modified DNA extraction mini-preparation protocol for Fusarium isolates. J Rap Meth Autom Microb. 2003; 11: 75-79.

26. Sambrook J, Fritsch EF, Maniatis T. Molecular Cloning: A Laboratory Manual, (2nd ed.) Cold Spring Harbor: Cold Spring Harbor Laboratory Press. 1989; 1051-1067.

27. Kamel AA. Bioinformatics tools and guideline for PCR primer design. Afr J Biotech. 2003; 2: 91-95.

28. Bogale $\mathrm{M}$, Wingfield $\mathrm{BD}$, Wingfield MJ, Steenkamp ET. Species-specific primers for Fusarium redolens and a PCR-RFLP diagnostic technique for distinguishing among three clades of Fusarium oxysporum. FEMS Micro Letter. 2007; 271: 27-32.

29. Altschul SF, Gish W, Miller W, Myers EW, Lipman DJ. Basic local alignment search tool. $J$ Mol Biol. 1990; 215: 403-410.

30. Thompson JD, Higgins DG, TJ Gibson. CLUSTAL $\mathrm{W}$ : improving the sensitivity of progressive multiple sequence alignment through sequence weighting, position-specific gap penalties and weight matrix choice. Nucl Acid Res. 1994; 22: 4673-4680. 
31. Tamura K, Dudley J, Nei M, Kumar S. MEGA4: molecular evolutionary genetic analysis (MEGA) software version 4.0. Mol Biol Evol. 2007; 24: 1596-1599.

32. Iqbal Z, Rehman M, Dasti AA, Saleem A, Zafar Y. 2006 - RAPD analysis of Fusarium isolates causing mango malformation disease in Pakistan. World $J$ Microb Biot. 22; 1161-1167.

33. Martin C, Roberts D, Weide MVD, Rossau R, Jannes G, Smith T. Development of a PCR-based line probe assay for identification of fungal pathogens. J Clin Microb. 2000; 38: 3735-3742.

34. Freeman S, Klein-Gueta D, Korolev N, Sztejnberg A. Epidemiology and survival of Fusarium mangiferae, the causal agent of mango malformation disease. Acta Hort. 2004; 645: 487 491.

35. Iqbal Z, Pervez MA, Saleem BA, Salman A, Altaf AD, Saleem A. Potential of Fusarium mangiferae as an etiological agent of mango malformation. Pak J Bot. 2010; 42: 409-415.

36. Marasas WFO, Ploetz RC, Wingfield MJ, Steenkamp ET. Mango malformation disease and the associated Fusarium species. Phytopathol. 2006; 96(6):667-672.
37. Steenkamp ET, Wingfield BD, Coutinho TA, Wingfield MJ, Marasas WFO. Differentiation of Fusarium subglutinans f. sp. pini by histone gene sequence data. Appl Env Microb. 1999; 65: 34013406.

38. Judelson HS, Tooley PW. Enhanced polymerase chain reaction methods for detecting and quantifying Phytophthora infestans in plants. Phytopathol. 2000; 90:1112-1119.

39. Leslie JF, Zeller KA, Logrieco A, Mulè G, Moretti A, Ritieni A. Species Diversity of and Toxin Production by Gibberella fujikuroi Species Complex Strains Isolated from Native Prairie Grasses in Kansas. Appl Env Micro. 2004; 70(4): 2254-2262.

40. Freeman S, Maimon M, Pinkas Y. Use of GUS transformants of Fusarium subglutinans for determining etiology of mango malformation disease. Phytopathol. 1999; 89: 456-61. 